\title{
Foreword: Sustainable animal production in the tropics: farming in a changing world
}

\author{
N. Mandonnet, M. Mahieu and M. Boval \\ INRA, UR143, Unité de Recherches Zootechniques, 97170 Petit-Bourg, Guadeloupe, France
}

Global animal production will face significant challenges over the next decades in order to meet the increasing demand for protein from a growing world population threatened by climatic change and changing social expectations. In the Tropics, these challenges are even greater as this is where high population growth (Genin, 2006) is often combined with a rising demand for livestock products (Steinfeld et al., 2006). Scientists, farmers and policymakers need to work together to identify innovative solutions. Opportunities have to be identified in three key areas: animal breeding and adaptation capacities of livestock to a changing environment, local feed and forage resources and their strategic use and farming systems that match territory and global markets with a focus on mixed farming systems.

The papers brought together in this issue of Animal are based on invited talks presented during the symposium 'Sustainable Animal Production in Tropics' (SAPT) held on the island of Guadeloupe in 2010 by INRA and CIRAD on behalf of the BSAS, EAAP and WAAP. The aims of the conference that were focused on tropical and subtropical humid areas, were to share knowledge and good practice, identify relevant solutions and fix priorities to meet livestock challenges. Gaps in scientific knowledge were also identified to highlight future research needs. Solutions and research areas were presented at the animal, feed resources and systems levels. The abstracts of the conference were published in Advances in Animal Biosciences (2010) and a selection of plenary papers were chosen for publication in Animal.

The first paper (Renaudeau et al., 2012) gives a very informative overview of the effects of a hot climate on livestock performance and presents a large panel of strategies to alleviate heat stress in farm animals: increase feed intake or decrease metabolic heat production, enhance heat-loss capacities and select for heat tolerance. It points out that the 'heatstress issue' will increase in the future if genetic selection for growth rate and milk production continues.

Referring to the Australian experience, the second paper (Burrow, 2012) relates the consequences of genotype $X$ environment interactions (GEI) on animal genetic resources management. The incidence of GEl across temperate and tropical environments on re-ranking of single nucleotide polymorphism is pointed out. Collaborative programs involving various countries and production systems, and different genotypes are needed to implement the characterization of livestock aptitudes and match the needs of tropical farming systems.

The third paper (Bishop, 2012) foresees the possibilities of breeding for resistance to nematode parasite infection, the most important disease affecting livestock production systems in developing countries. The bibliography demonstrates that conventional breeding for resistance is possible and suggests that it should be sustainable. However, with current technologies, genetic markers are likely to be difficult to incorporate into tropical breeding schemes from an economical and a logistical point of view.

The fourth paper (Boval and Dixon, 2012) puts forward the importance of grassland in the tropics. Pastures in the tropics are multifunctional as they provide numerous feed, goods and services. Diverse strategies for management of grassland ecosystems to balance these competing demands are reviewed: stage of regrowth of pasture, duration and frequency of grazing, crop residues and by-products, utilization of legumes; criteria and technologies to evaluate pasture managements are tackled.

The fifth paper that focuses on Latin America and the Caribbean (González-Garcia et al., 2012) reviews the potential and opportunities for mixed farming approaches as contextrelevant solutions to the special challenges existing in the tropics and analyses how research can support this development. The authors stress that active participation of local and regional actors, stakeholders and end-users in the identification of research priorities, as well as dissemination of technology innovation are needed.

As a conclusion for the future, research in animal production in the tropics has to promote interdisciplinary approaches combining animal sciences and social and economic sciences (economics, political science, management science, etc.) to better provide analytical grids to envision plausible or desirable levels of decision. The importance of developing models to integrate knowledge from analytical research and explore new scenarios was stated. Finally, the importance of maintaining and supporting in situ tropical research livestock production was stated. The next SAPT meeting is scheduled in 2013 during the EAAP meeting in Nantes (France). 


\section{Acknowledgments}

The authors of this foreword would thank M. Steele, P. Chemineau, B. Malpaux, J.B. Coulon, D. Boichard, P. Herpin, P. Caron and A. Rosati for their active participation in facilitating this conference and assisting in the dissemination of the information discussed and presented in the SAPT symposium. The International Scientific Committee and the Editorial Committee with G. Aumont, N. Silanikove, T. Lefrançois, D. Sauvant, R. Dixon, F. Jackson, H. Guerin, J. Noblet, F. Torres-Acosta, T.R. Preston, C. Devendra, P. Lecomte and W. Brand-Williams are also warmly thanked for their support and contribution.

\section{References}

Advances in Animal Biosciences 2010. International symposium on sustainable animal production in the tropics: farming in a changing world, November 15-19, Gosier, Guadeloupe, vol. 1, part 2.
Bishop SC 2012. Possibilities to breed for resistance to nematode parasite infections in small ruminants in tropical production systems. Animal 6, 741-747.

Boval M and Dixon R 2012. The importance of grasslands for animal production and other functions: a review on management and methodological progress in the tropics. Animal 6, 748-762.

Burrow HM 2012. Importance of adaptation and genotype $\times$ environment interactions in tropical beef breeding systems. Animal 6, 729-740.

Genin D 2006. Croissance démographique: quels impacts sur le développement durable. Retrieved October 25, 2007, from http://www.pro-environnement.com/ publications/vertitude-magazine/

González-Garcia E, Gourdine J-L, Alexandre G, Archimède H and Vaarst M 2012 The complex nature of mixed farming systems requires multidimensional actions supported by integrative research and development efforts. Animal 6, 763-777.

Renaudeau D, Collin A, Yahav S, de Basilio V, Gourdine J-L and Collier RJ 2012. Adaptation to hot climate and strategies to alleviate heat stress in livestock production. Animal 6, 707-728.

Steinfeld H, Gerber P, Wassenaar T, Castel V, Rosales M and de Haan C 2006. Livestock's long shadow - environmental issues and options. Food and Agriculture Organisation of the United Nations, Rome, Italy. 